\title{
The spatial cleansing of Xinjiang: Mazar desecration in context ${ }^{*}$
}

\author{
Rian Thum
}

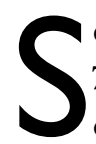

ometime between 10 and 17 March 2018, on a high sand dune 75 kilometres from the town of Niya, a beloved historical monument disappeared (Kuo 2019). For at least 450 years, the site had drawn pilgrims from across the expanse of Altishahr-the southern half of what is now known variously as Eastern Turkistan or Xinjiang (Düghlāt 1996: 190). Pilgrims came to be in the presence of Imam Je'firi Sadiq, a founding father and hero who had died there 1,000 years earlier while bringing Islam to their homeland. At his tomb, they wept, prayed, and gained blessings from contact with the physical structure.

The white-painted tomb had the shape of an ordinary grave marker, but on the scale of a giant, like a grave for someone 6 metres tall, resting on a platform 15 metres square. Some pilgrims wrote graffiti in a wooden, box-like prayer house erected in the sand nearby, recording their shared presence with the saint in the very location where their society and their history were born. All around, flags and strips of cloth whipped loudly in the wind-thousands of offerings tied to various sacred structures, testifying to the crowds of fellow Uyghurs who had come over the years to venerate this point of historical origin and connection to the divine. In the early autumn, pilgrims came in especially large numbers, cooking communal meals in a gigantic pot and sleeping near the site. All of this disappeared in the middle of March 2018, leaving an empty dune. ${ }^{1}$ In the ensuing two years, the Chinese state has destroyed and desecrated Uyghur historical and holy places at a scale unprecedented in the history of Eastern Turkistan (Altishahr, Xinjiang) as a Chinese-dominated region. Among the demolished places were mosques, which have received the

\footnotetext{
I This description is based on the author's visit during the pilgrimage festival of 2007. Other shrine descriptions throughout the article are based on the author's fieldwork in 2003, 2004-05, 2007-08, 20I0, 20I3, 20I5, and 2017.

"This essay was originally published in the Made in China Journal (vol. 5, no. 2, 2020), doi.org/ | 0.22459/MIC.05.02.2020.04.
} 
bulk of international media attention. But another kind of sacred site, less legible to outsiders, has arguably been a more significant crux of desecration. This is the mazar, a point on the landscape that holds particular numinous authenticity, a connection to and presence of the divine that surpasses the sacredness even of the mosque as a physical structure.

For many Uyghurs in urban contexts, mazars have become peripheral, irrelevant, or entirely forgotten. But most Uyghurs live in rural environments, where mazars have commonly functioned as community resources, historical archives, arenas of dispute, and independent social actors. At a mazar, one can seek fertility or healing. The pilgrim can learn about the history of the shrine's buried saints, and thus of her own land. Local religious leaders can promote their understandings of right behaviour against the claims of others. And the shrine itself can intervene in the everyday lives of its constituencies by entering their dreams or bringing rain.

Mazars are nearly always marked by some physical construction, ranging from high domes with green, glazed tiles to nothing more than a few flags on crooked twig poles (Dawut 2001). Most are graves, purported to hold the physical remains of an individual whose accomplishments in lifewhether scholarly, heroic, or miraculous-are thought to grant his or her immortal personage a closeness to God that can be shared with the living. Mazars can also be other points of transcendent contact: sacred trees or springs, the footprints or stopping places of holy people, or the locations where sacred personages disappeared. Such non-burial sites represent a tiny minority of mazars, but they demonstrate the capaciousness of the term and the potential for points on the landscape to become sacred by multiple means. Whatever the physical and narrative form of a particular mazar, in practice, 'mazar' denotes the most immediate, tangible manifestation of the sacred in physical and geographical form.

The miraculous power of a mazar's substance is visible in the habits of pilgrims. Women who seek to become pregnant will sometimes reach into a crack in a mazar's walls or a hole in the earth on which the mazar sits, grasp the first thing they touch, such as a small clod of dirt or mortar, and swallow it. Such faith in the power of the mazar's physical material has been prominent enough to earn the condemnation of reform-minded Muslims in the region, as in the case of the early twentieth-century critic Abdu Vali Akhon, who complained about 'common' pilgrims who 'rub their faces and eyes on the shrine's walls' (Abdu Vali Akhon 1905: 162). Another reformist of that era, visiting Kashgar from Ottoman lands, similarly complained about people 'rubbing their faces on sheep horns ... 
and on cow tails' kept at the shrines (Kemal 1925: 94). Especially devoted pilgrims, such as a man I met at a tomb in Yarkand in 2007, will sometimes sleep inside a mazar structure itself, in the hope of receiving miraculous inspiration in their dreams.

These properties of the mazar stand in some contrast to attitudes towards mosques. I have not been able to document any similar interactions with the physical structure of a mosque, even when the mosque is attached to a mazar. This is not to say that mosques are not sacred. They provide a space of purity where worshippers can engage in devotions towards God, and the collective acts of devotional prayer can generate miraculous effects. In Kashgar in the 2010s, women would line up at the exits of the Id Kah Mosque and hold out food for departing worshippers to blow a puff of air upon, lending the food curative properties. But here the curative power was generated by the activities and personal traits of other worshippers, not the physical substance of the mosque.

\section{The nature and goals of desecration}

Authorities in Xinjiang clearly share some awareness of the power of mazars. The circumstances of the destruction of Imam Je'firi Sadiq's tomb show that it was the mazar itself that attracted the authorities' attention, not the economic value of the land. The remote and barren dunes on which the mazar stood have no other use. Elsewhere, some aspects of China's assault on sacred spaces have involved economic incentives. More than 100 graveyards have been destroyed across Xinjiang in the past three years, in some cases making valuable urban land available to developers or the state (Xiao and Yiu 2019; Rivers 2020). But the destruction of Je'firi Sadiq's tomb paved the way for precisely nothing. Destruction seems to have been the point, not a sacrifice to some economically valuable end.

For decades, authorities have been nervous about the large festivals (seyla) that some mazars inspire. Officials across China tend to be wary of potential for independent gatherings to create alternative sources of political power or develop into protests. Across those decades, however, the state demonstrated that complete destruction of a mazar is not necessary to prevent gatherings. For more than 20 years, authorities have prevented mass pilgrimage to the only site more revered than Jefiri Sadiq's mazar: the Ordam Padishah mazar, in the desert outside Yengisar. The occasional lucky or connected party slipped through the police net around the site from time to time (I was arrested when I tried), but the famous festivals 
of Ordam Padishah, with their tens of thousands of attendees, were successfully killed off (Harris and Dawut 2002). Based on my own visits, I can confirm the same for Chūje Padishahim mazar (near Yengisar), Ujme mazar (near Khotan), and, more recently, Imam Asim mazar (also near Khotan). Even the Je'firi Sadiq mazar had already been closed to all pilgrimage sometime after my successful 2007 visit, and I was turned away when I returned in 2015 . The destruction was not needed to prevent pilgrimage; destruction appears to have been an end in and of itself.

Even when locked behind police roadblocks and roadside informants, mazars wield power. They enter people's dreams and give them guidance. One can petition them from a distance or send personal prayers ( $\left.d u^{\prime} a\right)$ in their direction, as I witnessed a man do after being turned away from Imam Je'firi Sadiq mazar in 2015. Simply knowing that the mazar is standing out there between the Uyghur-inhabited oases maintains a community tie to history and the land. I met one of the handful of lucky Uyghurs who managed to reach Ordam Padishah long after it had been closed, and she told me what happened when she mentioned her good fortune, standing outside a village mosque, weeks later. The men to whom she was talking began weeping and begged to collect some of the dust of the mazar from her jacket. To judge from publicly available satellite imagery, Ordam Padishah is now gone, too (Google Earth 2020: $\left.38.9144^{\circ}, 76.6567^{\circ}\right)$.

After the Notre-Dame cathedral in Paris was partly destroyed by fire in April 2019, the French government began a billion-dollar remediation that continues today. Fallen stones are cleaned with lasers. Previously inaccessible materials are examined for clues that can shed new light on the monument's history. Scientists analyse lead from the fallen spire and trace its environmental impact on the Seine River and beyond. And a team of anthropologists studies the emotional trauma that the monument's damage has inflicted on Parisians and visitors from around the world (Lesté-Lasserre 2020).

The many Uyghurs whose relationship to Ordam Padishah parallels the Parisian and global attachments to Notre-Dame would surely welcome a similar effort. The rubble of Ordam's destruction holds abundant clues to its history. Archaeologists could undertake tree-ring dating of the sort that scientists have planned for Notre-Dame's fallen timbers. Ancient refuse and offerings left by pilgrims could reveal changes in patterns of worship over the centuries. Because many of Xinjiang's desert shrines sit on or near older Buddhist sites, Ordam's destruction may have revealed traces 
of even earlier sacred monuments. It is unlikely that many Uyghurs inside Xinjiang have learned yet about the destruction of Ordam Padishah, but when they do, the emotional trauma will be no less acute than in Paris after the cathedral fire.

Of course, in the case of Ordam Padishah, the cultural destruction is not accidental. The shortest distance from Ordam Padishah to cultivated land is 14 kilometres, over soft sand and high dunes. The expense and effort required to bring equipment capable of obliterating Ordam's network of monuments, mosques, rest houses, and mounds in the open desert must have been substantial. The recent pattern of government activity thus suggests that further destruction and desecration in Xinjiang are far more likely than the kind of state-led effort at recovery, remediation, and reparations occurring in Paris. As at Je'firi Sadiq mazar, the land around Ordam Padishah is remote and barren, and the shrine has been replaced with nothing; destruction of the Uyghurs' most sacred site seems to have been the goal, as part of the government's broader efforts to define and control Uyghur material culture and history.

Full obliteration of the sort that Jefiri Sadiq and Ordam Padishah suffered is not the only attack that Uyghur holy places have suffered. The wave of mazar closures of the past three decades was already a form of destruction. Mazars are continually created and recreated through pilgrimage. Their structures accumulate mass as pilgrims bring flagpoles, lengths of cloth, sheep horns, oil lamps, animal skins, and other ephemeral offerings. The offerings pile up and the accumulated flagpoles sometimes reach 10 metres high. The slow deterioration of wood, cloth, and skin testifies to the age and continuity of pilgrimage. The constant replenishing of the flags and skins manifests the continued power of the mazar over its constituencies and reminds the pilgrim that his or her devotion embeds them in a community larger and less knowable than the circles of their home village. Shrine closure interrupts this continuous production of the sacred site.

At the mazar of Imam Asim, near Khotan, it almost looks like local authorities share this understanding of continual incarnation through pilgrimage. Recent photos show that the mudbrick structure of the tomb itself was unharmed as of 2018 (MarcelTraveller 2018). But the site is unrecognisable. The associated mosque has been demolished; the mazar proper has been denuded of its flags, offerings, and wooden railings. The grave marker, which sits atop a low mudbrick building, was previously invisible behind a forest of pilgrims' flags, their poles 
affixed to the wooden fence on the building's roof. It now stands naked, motionless, and monochrome, shorn of the colourful, flapping attire of sacred offerings. Authorities have stopped short of total obliteration. But they have crossed the wooden fence into a zone that is forbidden even for most believing pilgrims and desecrated the mazar by denuding it of its external display of community veneration.

For officials who came into close contact with them before the closures, mazar activities and pilgrimage festivals made otherwise hidden troubles visible. Particularly at times of mass pilgrimage, shrines revealed themselves as alternative sources of legitimacy and authenticity outside the control of the state. The crowds of pilgrims in group prayer demonstratednot just to observers, but also to pilgrims themselves-the emotional power of collective action. The mixing of devotees from far-flung regions circumvented the ubiquitous state control of long-distance communication. Even outside of the large pilgrimage festivals, daily, small-scale devotions revealed the state's tenuous hold on life-cycle rituals, knowledge production, and medical care. In a more general way, the architectural, sonic, and overall aesthetic qualities of the shrine made it immediately clear that it was a world entirely alien to the self-consciously modernist, 'harmonious', and totalitarian society pursued by the Chinese state.

\section{The history and scope of desecration}

Although the acts of extreme desecration and demolition described above seem to have begun in 2018, states have always been interested in Uyghur mazars as centres of economic and political power. When the Qing Dynasty's Qianlong Emperor (1711-99) conquered Eastern Turkistan in 1759 and incorporated it into the new administrative entity of 'Xinjiang', he issued an order to protect and even repair the region's mazars. However, in the succeeding 150 years, the Qing state would frequently confiscate mazar landholdings in the wake of rebellions, targeting particular mazars that were associated with rebel factions (Zhang 2016: 130-31). Nonetheless, beyond the occasional economic dispossession of mazars, the Qing did little to disrupt pilgrimage or physical structures. On the contrary, their system of indirect rule gave local elites latitude to perpetuate and, in some cases, even promote mazars (Brophy and Thum 2015). The tombs of some Qing client-administrators themselves became mazars. 
Chinese officials ended the system of indirect rule in the late nineteenth century and began to introduce assimilationist policies, but even then mazars seem to have largely escaped notice. The earliest attempt to control sacred sites on a systematic scale may be the efforts of warlord governor Sheng Shicai (who ruled from 1933 to 1944) to bureaucratise the landholdings of mazars, all of which he confiscated in the mid-1930s (Sugawara 2016: 155; Zhang 2016: 132). Landholding again brought mazars under state scrutiny in the 1950s, as the newly arrived Chinese Communist Party confiscated their land and turned their religious personnel into state employees (Wang n.d.). Personnel were gradually reduced until, during the Cultural Revolution, mazars throughout Xinjiang were closed completely.

With the loosening of restrictions on cultural and religious practices in the 1980s, mazars sprang back to life in two different ways. Some, like Ordam Padishah, enjoyed a grassroots revival of festivals and ordinary pilgrimage. Others-most notably, Afaq Khoja in Kashgar-were transformed by the state into museum-like tourist attractions. This museumification was the earliest wave of mazar disruption in reform-era China.

The museumification of Afaq Khoja-once a site of large gatheringskept pilgrimage to a trickle. The few members of the mazar's rural constituency who could afford the high-priced entry ticket discovered a sacred site with no religious authorities, a secularised environment denuded of visible offerings, and sanctuaries full of Han Chinese tourists, souvenir sellers, and guides. Pilgrimage festivals and overnight activities were prevented entirely. Similar efforts at the Altunluq ('golden') cemetery in Yarkand, the Sultan Sutuq Bughrakhan mazar in Artush, and the Yusup Khas Hajip mazar in Kashgar lacked the resounding tourist success of Afaq Khoja, but similarly curtailed pilgrimage. The important mazar of Eshabulkehf, near Turpan, continued to receive somewhat more pilgrims (though no large gatherings), perhaps due to looser and more affordable ticketing policies that exempted some locals.

In the late 1990s and early 2000s, as pilgrimage festivals expanded at mazars that had escaped museumification, authorities began imposing restrictions. They levied entry fees at Imam Asim (2 yuan) and Imam Jefiri Sadiq (50 yuan), adding strict identity registration procedures at the latter. The closure of Ordam Padishah in 1997 is the earliest documented for the post-reform period, but others followed. By 2008, authorities had closed the shrines of Ujme (Khotan) and Chüje Padishahim (Yengisar), both of which had hosted large festivals. By 2015, there were no shrine festivals taking place anywhere in Xinjiang. 
The demolitions and desecrations that began in 2018 have so far left most minor mazars unscathed. Hundreds or perhaps thousands of small mazars punctuate the sacred geography of Xinjiang. These provide some of the same devotional and miraculous functions of the famous mazars, without the large gatherings or regional community-building effects. Satellite photos suggest that a handful of more historically significant mazars with impressive domed structures have also been spared-notably, Yarkand's two most famous holy sites, Chilten and Muhemmed Sherip. In the early 2000s, Chilten drew a steady flow of pilgrims on market days and holidays but did not host large gatherings of the type that led to the closures of other mazars. However, given the criminalisation of most religious activities, all mazars are likely to be under some level of restriction or de facto closure.

Full demolition and desecration have so far been aimed at mazars that have drawn large crowds, have region-wide reputations, and have not been museumified. My fieldwork among pilgrims conducted between 2003 and 2017, combined with historical documentation, suggests that among the hundreds or thousands of Uyghur mazars, five have exceptionally strong and historically deep regional reputations for holiness (Table 10.1). The destruction of Imam Jafiri Sadiq and Ordam Padishah has now taken two of those most widely revered mazars off the map. The remaining three have physically survived as museumified destinations for Han Chinese and foreign tourists. Among these five sites, the newly demolished Ordam Padishah was often described-both by living pilgrims and by historical sources-as the holiest site in Eastern Turkistan (Jarring 1935).

Table 10.I Status of mazars that once hosted large gatherings of pilgrims (seyla)

\begin{tabular}{|l|l|l|}
\hline Shrine name & Nearest town & Status as of $\mathbf{2 0 2 0}$ \\
\hline Imam Je'firi Sadiq* & Niya & Demolished \\
\hline Turt Imam & Khotan & Unknown, standing \\
\hline Imam Asim & Khotan & Closed and desecrated \\
\hline Ujme & Khotan & Closed, physical status unknown \\
\hline Ordam Padishah* & Yengisar & Demolished \\
\hline Chuje Padishah & Yengisar & Closed, standing \\
\hline Afaq Khoja* & Kashgar & Museumified \\
\hline Eshabulkehf* & Turfan & Museumified \\
\hline Sultan Sutuq Bughrakhan* & Artush & Museumified \\
\hline
\end{tabular}

Note: Asterisks denote the five most sacred mazars in the Uyghur region - my subjective determination based on fieldwork among pilgrims conducted between 2003 and 2018 and historical accounts. Imam Asim is a borderline case. It attracted exceptionally large numbers of pilgrims, but historical sources do not present it as one of the region's most sacred places. 
While authorities have destroyed Uyghur historical monuments, they have promoted their own shrine-like structures-built from the 1980s onward but often claiming antiquity. For example, in 1994, they built Kashgar's 'Ban Chao Memorial Park' (班超纪念公园), which was expanded in the 2010s into the 'Pantu City Scenic Area' (盘索城景区), a park with statues, reliefs, and architectural imitations of ancient Chinese fortifications. It commemorates the period between 73 and $102 \mathrm{CE}$, when the Eastern Han dynasty conquered and briefly controlled the region under the Chinese general, Ban Chao (Millward 2009: 24). The memorial and park are claimed to occupy the site of Ban Chao's original fortifications. Chinese tourists from throughout the country are encouraged to visit this 'patriotic education base' (爱国主义教育基地), where they learn about the state's vision of a Han-dominated national community, in much the same way that Uyghur pilgrims once learned about their community's history at Ordam Padishah mazar. Recognising that entry fees can disrupt the functions of a pilgrimage site, authorities recently made entry to the park free of charge (Xu 2018).

\section{Contemporary context}

Mazar desecration is part of a larger set of policies that raze the Uyghur built environment, reconfigure Uyghur geography, and eradicate the spatial underpinnings of Uyghur culture. Though a comprehensive enumeration of Chinese spatial reengineering policies is not practicable here-they are simply too numerous - a few examples will demonstrate the extraordinary scope of state efforts to replace Uyghur built environments and uproot geographically embedded expressions of Uyghur culture. As these examples show, almost no part of Uyghur life is untouched by state destruction of the Uyghur built environment, suggesting that state attacks on apical cultural nodes like prominent mazars are part of a larger effort to disconnect Uyghur experiences and identities from the landscape.

The recent spate of prominent mosque demolitions and desecrationsincluding the most important mosques of Karghalik and Keriya-followed a large 'rectification' campaign from late 2016, which 'demolished nearly 70 per cent of mosques in the city' of Kashgar, according to Wang Jingfu, the head of Kashgar's Ethnic and Religious Affairs Committee, along with an unknown number of mosques in other parts of Xinjiang (Hoshur 2016). The mosque destructions closely followed the introduction of bans on praying in public, which had left homes and mosques as the only 
remaining spaces where religious devotions were permitted. This means the destruction of mosques has achieved an even greater constriction of religious space than it would have under ordinary conditions.

Both homes and mosques eventually became unsafe for prayer due to the combination of surveillance and arbitrary internment. The fanghuiju program (访惠聚 being an abbreviation of 访民情、惠民生、聚民心， which means 'inspect the situation of the people, improve the welfare of the people, gather the hearts of the people'), which sent more than one million Han Chinese government workers into Uyghur houses, enabled direct monitoring of Uyghurs' religious devotion at home (Byler 2018; Xinjiang United Front Work Department 2017b). Surveillance cameras in mosques further tightened the net on those who prayed. Authorities used the frequency of prayer as an indicator of (un)trustworthiness, ultimately sending people who prayed frequently to the internment and indoctrination camps. One leaked document shows that simply having family members who engage in too many religious activities can lead to internment (Zenz 2020).

As Timothy Grose describes in his essay in the present volume, homes were also transformed in more physical ways. Chinese state media outlets have published multiple reports of official efforts to change Uyghur household furnishings. These usually explicitly target the supa (土炕), a raised platform, often heated from below, on which many Uyghurs eat meals and sleep. However, many reports also mention other types of furniture throughout the house and complete transformations of household interiors as part of the 'beautiful courtyard' (美丽庭院) campaign. Because supas are often built into the structure of houses, their removal is labour intensive. In addition to serving as large communal beds, shared by numerous family members, supas are often used for activities that range from hosting guests to doing school homework. The shift to Western-style beds dedicated to sleeping singly or in pairs substantially changes the everyday interactions within a household. Authorities are aware of this, noting that children and adults will need to sleep separately (Xinjiang Minsheng Net 2018) and commanding Uyghurs to 'abandon the bad customs of laying out carpets, eating and sleeping on the supa, and getting on the supa to do homework' (Zero Distance Awat 2019).

Several ethnic groups across rural areas of northern China, including Han Chinese, use supas, and the province of Gansu has seen its own 'supa reform' (土炕改造) campaign. The different ways officials both execute and portray 'supa reform' in Gansu and Xinjiang show how 
Xinjiang officials enlist and reframe wider government policies as tools for transforming Uyghur culture. In Gansu, supa reform is pursued as an environmental policy, designed to reduce emissions from the coal fires that heat the supa (Zheng 2017). In most cases, the goal is to convert coal-heated supas to electric-powered supas, often through subsidies (Gansu Daily Net 2019).

In Xinjiang, on the other hand, the environmental justification is largely absent, and supas are removed rather than converted. Instead, as Timothy Grose (2020) has shown through his analysis of state media reports, officials have adopted a civilising discourse that presents Uyghur household furniture as backward and uncivilised. Xinjiang's highest-ranking Uyghur official, Shohret Zakir, modelled this attitude in his comments to state media, saying:

Only by having farmers, especially farmers in poor areas of Southern Xinjiang [where most Uyghurs live], personally experience the benefits of a modern way of life, can we make modern civilised life deeply penetrate farmers' souls ... Grassroots leaders and cadres should ... guide farmers, step by step, to abandon backwards customs and live a modern lifestyle. (Xinjiang Daily 2018)

Meanwhile, in a pattern similar to the museumification of mazars, the state has made a tourist attraction out of the very object it is destroying in Uyghur villages. Supas, transformed into odd shapes, now stand along the roads of the tourist simulacrum that replaced Kashgar's old city. Before the demolition of Kashgar's Uyghur urban core between 2001 and 2017, typical homes were mostly featureless on the outside, with small windows and little in the way of decoration. The interiors, by contrast, featured lush courtyards, elaborate woodwork, colonnades, and interior reception rooms with intricate niches holding display ceramics. The new Kashgar has turned the Uyghur home inside out. Above one of the new roadside supas are shelves holding jars and a teapot. An old column-likely salvaged from a demolished interior courtyard-now stands in front of an exterior door. Supposedly 'backward customs', increasingly off limits to Uyghurs themselves, are now on display for the primarily Han tourists who are driven through the new 'old city' on electric carts. 

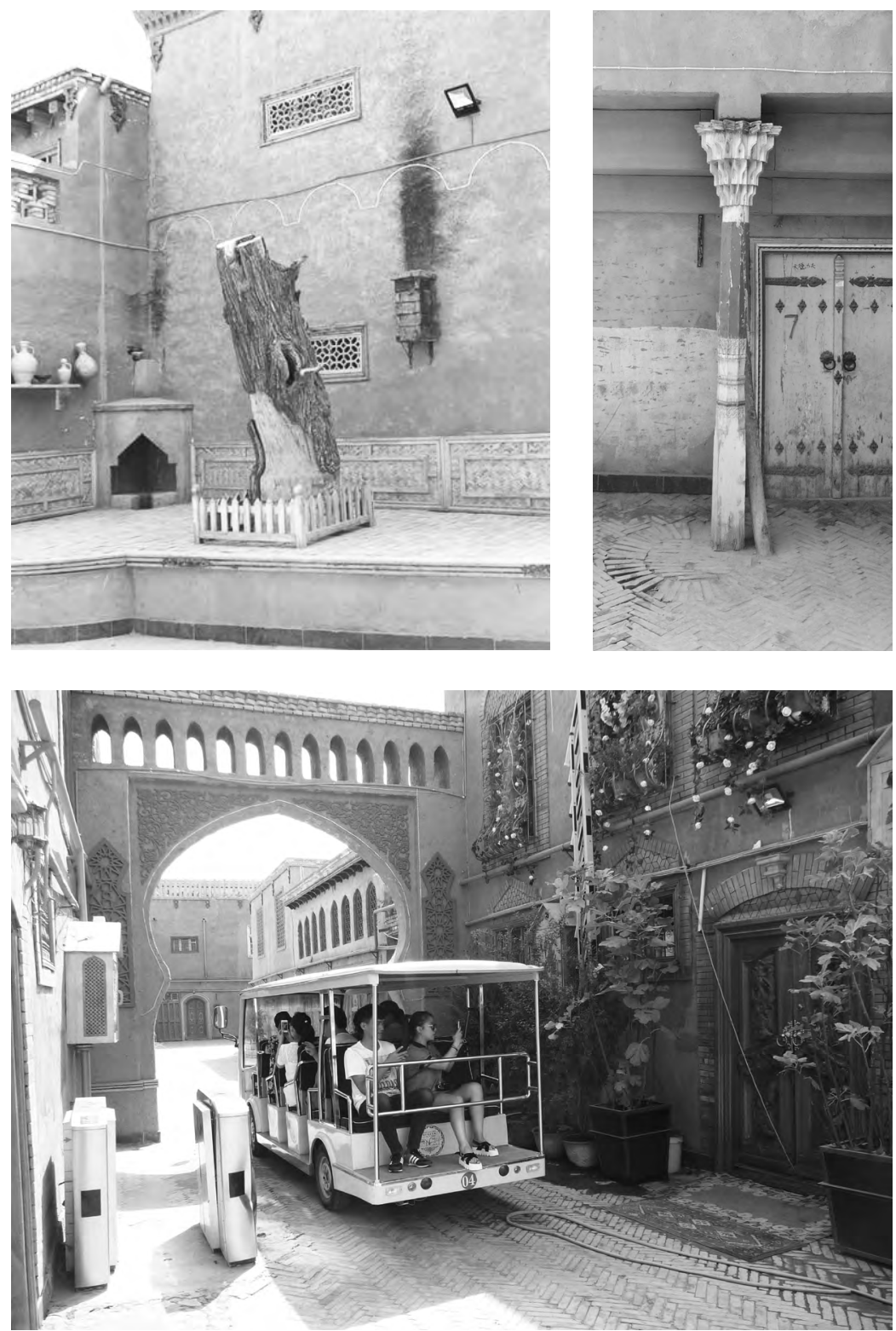

(Top Left) Plate 10.1 Supa-like platform and mock hearth outside houses in the new Kashgar Old City, 20 I 5. (Top Right) Plate 10.2 Interior column repurposed for exterior use along a public street in the new Kashgar Old City, 20 15. (Bottom) Plate I0.3 Tourists entering the new Kashgar Old City, 2015. Photos by the author. 
Between 2000 and 2016, Kashgar was the only historic Uyghur urban core to suffer such wholesale obliteration and replacement. In other towns, piecemeal development slowly transformed and eroded the Uyghur built environment (Kobi 2016), but there was little evidence of state-directed demolition of historic Uyghur neighbourhoods on the scale of Kashgar. However, satellite images reveal that in the years after 2016, authorities oversaw the destruction, in whole or in part, of the old cities of Khotan, Yarkand, Kargalik, and Keriya. ${ }^{2}$ The most common type of replacement structure is the multistorey apartment building.

The example of Kashgar, which has been studied in detail elsewhere, gives a sense of what is involved in the replacement of Uyghur neighbourhoods (mähällä) with apartment blocks. Many residents had no choice but to relocate to multi-storey apartment blocks outside the city, and the change has involved disruptions to a wide range of social phenomena, including inheritance practices, life-cycle rituals (funerals, weddings, and so on), elder care, neighbourhood solidarity (mahalladarchiliq), sleeping arrangements, patterns of cohabitation, and networks of reciprocity (Pawan and Niyazi 2016; Liu and Yuan 2019). In short, the move from mähällä to apartment compound represents a shift to an entirely new way of life. Detailed information about the demolition and replacement of other old cities from 2016 is unavailable as yet, and research in the affected towns is almost impossible for outsiders. However, the dislocation and cultural disruption that Kashgar's old-city residents have experienced gives a sense of the changes that residents of demolished neighbourhoods in Khotan, Yarkand, Karghalik, and Keriya likely face.

Seen in the context of the comprehensive reengineering of Uyghur spaces, the destruction of prominent mazars represents one extreme on a spectrum. On one end are sites of daily, highly localised, and sometimes mundane interactions with the built environment, for example furniture, house plans, and street layouts. On the other end, famous mazars are sites at which people connect on rare occasions with a transregional, transtemporal, and transcendent community. For those who make pilgrimages in person, forgiveness, merit (sawab), healing, and the intermingling with strangers tie these weighty communitarian meanings to their personal lives. For those who cannot make the pilgrimage, the mazars exert such powers from a distance. Chinese state interventions across the spectrum

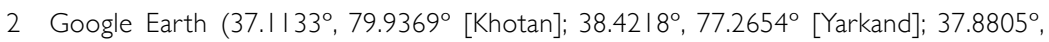
$77.4153^{\circ}$ [Karghalik]; and $36.8501^{\circ}, 81.6706^{\circ}$ [Keriya]). 
of the built environment threaten a disruption of Uyghur lifeways and understandings that straddles the symbolic and the practical, the sacred and the mundane, transforming geography and space as they intersect with practices, discourse, and knowledge.

\section{Graveyards}

At graveyards, the widespread state cleansing of intimate spaces with individualised or highly local significance intersects with the mazars' political and symbolic power. Because mazars are most often tombs, the boundary between ordinary graves and mazars is permeable. That line is also blurred by the widespread desire to be buried near a mazar. The tombs of saints-famous and parochial-are often surrounded by the graves of those who were prominent enough in their communities to access prime sacred land for their final resting places. The eminence of these figures, and the prominence of the saints beside whom they lie, often leads to their graves being treated as parts of the mazars themselves. A grave with a large enough marker, near enough the saint's tomb, will accumulate substantial offerings of its own, even from pilgrims who profess ignorance of the tomb's occupant. An inverse phenomenon also appears, which is that physically remarkable graves in a cemetery are often treated as, and thus become, mazars, possibly through the general association between mazars and graveyards.

As discussed above, the most widely renowned mazars appear to have been disproportionately targeted for destruction. However, many very minor mazars have also been destroyed, not because they are mazars, but because they sit in one of more than 100 Uyghur graveyards demolished by the Chinese state since 2017. Many Uyghurs have thus witnessed, in one act of destruction, the simultaneous desecration of their family members' graves and the demolition of their local mazars-sites that, despite not attracting substantial numbers of long-distance pilgrims, held similar connections to the divine and to community history at a local level.

For the moment, I only have access to the reactions of Uyghurs in exile, but the desecrations appear to have had predictably devastating effects on local communities. Some of these are documented in interviews by journalists and by Bayram Sintash (Rivers 2020; Sintash 2019). The phenomenon is widespread. Agence France-Presse documented the destruction of 45 cemeteries and CNN more than 100 (AFP 2019; Rivers 2020). 
The reasons given for graveyard destruction vary. The central Uyghur graveyard and shrine in Khotan were demolished for the 'city's development' and to create 'open spaces' (Khotan Government 2019). Authorities in the Yili region cited the need for a new fire station as the reason for destroying another graveyard (Zero Distance Yining 2019). Much like the case of 'supa reform', the graveyard destructions align with a nationwide program-in this case, 'funeral and burial reform' (殡葬整治) (Ministry of Civil Affairs 2018; Xinjiang Civil Affairs Department 2018). Outside Xinjiang, this campaign targets the unapproved burial of individuals in forests, the construction of 'luxury' tombs, and the creation of new, unapproved cemeteries. It is often framed as an environmental effort (She County People's Government 2020). Overall, the national campaign is aimed primarily at controlling the creation and expansion of cemeteries, rather than destroying longstanding, often historically significant, cemeteries as has happened in the Uyghur case.

The political and symbolic ramifications of this uprooting of Uyghur bodies and history from the land are interwoven into strains of Uyghur historical consciousness that are shared widely today. A story told to me by a young Uyghur man in a southern oasis gives a sense of the significance of death and burial, and the connection they enact between communities and the land.

Perhat, who is most likely still alive, was an urban and, in the context of his largish oasis town, urbane man in his late twenties when he volunteered a fictional tale he said came from a book. I did not record his telling in audio or written form, thinking it must be a well-known written tale I would track down later. I asked where he read it, but my subsequent searches in the books he named as possibilities have not turned up a close match. The terminology he used suggested a story from the famous 1996 novel by Memtimin Hoshur, Sand Buried City (Qum Basqan Shahr), which describes the fall of a Uyghur city to a conquering king, but I have been unable to find the tale there. I paraphrase here from memory, hoping the imprecision of my recall is outweighed by the explanatory value of his recounting. If it does have a written precedent, I hope a reader will inform me:

The Sun King desired our homeland. He sent his vizier here. The vizier did not engage in any political machinations, but instead set up a home, took a wife, and lived a modest life. The people welcomed him, treating him as a guest. Eventually, he died and 
was buried here, in our land. This was, in fact, precisely what the Sun King had hoped for. The vizier's tomb became a foothold for the Sun King, a claim upon the land. Before long, the armies of the Sun King followed, and our land became a part of the Sun King's empire. The Sun King had taken the land by sending someone to die here.

This story illustrates not just the political significance of graves, but also an awareness of their power to connect living people to the land. The Sun King's soldiers could have conquered the land with or without a grave. But the basis of sovereign ownership preceded conquest and was effected instead by the linking of death to the landscape. It is a Uyghur story about the primacy of tombs in connecting community and political power to geography.

\section{Different symbols, same grammar}

The rootedness of Uyghur communities in land and the built environment is hardly unique. Though individual phenomena described here may be particular to Uyghurs, and may need some explanation for outsiders, Uyghur geographies are hardly exotic expressions of human relations to land and space. Similar patterns play out across the world. Even the Chinese state shares some Uyghur understandings of space and place. As much as China's settler-colonial regime depicts Uyghur-land relationships as backward, it seeks to create analogous interments of its own. Uyghurstyle graves are replaced with 'modern' graves that mark the state's control and new, shrine-like monuments to Chinese control are erected, such as the Ban Chao Memorial in Kashgar. This is one message of the Sun King story. The symbols are different, but the grammar is familiar. The actions of the Chinese state suggest that mazars are just as significant as Uyghur pilgrims believe they are.

As the Chinese state works to coopt and disrupt Uyghur geographies, it also embeds itself further in the global history of settler-colonial regimes. The desecration of shrines, the forced reordering of household space, and the demolition of cities in the name of modernity, civilisation, and development have all been common tactics of conquering empires and, especially, settler-colonial projects around the world. To this list we may add the coerced movement of Uyghurs to factory work outside Eastern 
Turkistan (see Byler's Chapter 12 in this volume). There could hardly be a more literal and explicit example of Tuck and Yang's argument that 'everything within a settler colonial society strains to destroy or assimilate the Native in order to disappear them from the land' (2012:9). ${ }^{3}$

The Chinese state's program of arbitrary internment, which has swallowed up a million or more Uyghurs, has no doubt facilitated the cleansing of Uyghur geographies and sacred sites. When Uyghurs can be abducted into camps for activities like refusing to watch state television, using foreign mobile phone apps, or being related to someone who wanted to travel abroad, protesting the destruction of a mazar is unthinkable. Many of the mazars' constituents were likely already victims of the internment program, because mazar-related activities have been designated as 'illegal religious activities' or 'signs of potential extremism', sometimes retroactively (Xinjiang United Front 2017a). And the most renowned Uyghur scholar of mazars, Rahile Dawut, has been disappeared since late 2017. Uyghurs are unable to even document the destruction, much less resist it.

One historically deep strain of Uyghur thought on sacred places offers a possible future for the desecrated and destroyed mazars. In the tazkirasmanuscript texts that act as explanations and sometimes liturgy for famous mazars - the mazar is often figured as an enduring point of significance on the landscape, independent of human-made structures. It can even be argued that the sacredness of the place preceded the saint's arrival on the spot (Thum 2014: 126 ff.). This increases the likelihood that future generations of Uyghurs, perhaps living in a postcolonial or at least less repressive reality, will return to the dunes of Imam Je'firi Sadiq and Ordam Padishah to build new memorial structures, and pilgrims will renew their visits, bringing new accretions of offerings. In this possible future, the mazars, no less sacred than they were before the Chinese state's attacks, have the potential to again serve as nodes for a Uyghur geography linking Uyghur pasts, presents, and futures to Uyghur lands.

However, this is only one possible future among many. And it is remote from the present reality of destruction. In a 2012 interview, before the shrine demolitions and before her own disappearance, Rahile Dawut described what the erasure we are now witnessing would mean:

3 I am grateful to Darren Byler for pointing out this passage. 


\section{XINIIANG YEAR ZERO}

If one were to remove these material artifacts and shrines, the Uyghur people would lose contact with the earth. They would no longer have a personal, cultural, and spiritual history. After a few years we would not have a memory of why we live here, or where we belong. (Manzi 2013)

In that interview, Dawut also pointed to the words of a Uyghur beggar she once met: 'When the mazar is at peace, the people are at peace. When the people are at peace, the rulers are at peace.' 
This text is taken from Xinjiang Year Zero, edited by Darren Byler, Ivan Franceschini and Nicholas Loubere, published 2022, The Australian National University, Canberra, Australia.

doi.org/10.22459/XYZ.2021.10 